\title{
Spectroelectrochemical Studies of Uranium and Neptunium in LiCl-KCl Eutectic Melt
}

\author{
I. B. Polovova, C. A. Sharrad ${ }^{\text {b }}$ I. May ${ }^{\text {b }}$, B. D. Vasin ${ }^{\mathrm{a}}$, \\ V. A. Volkovich ${ }^{\mathrm{a}}$, and T. R. Griffiths ${ }^{\mathrm{c}}$ \\ ${ }^{a}$ Department of Rare Metals, Ural State Technical University-UPI, Ekaterinburg, 620002, \\ Russia \\ ${ }^{\mathrm{b}}$ Centre for Radiochemistry Research, The University of Manchester, Manchester, M13 \\ 9PL, UK \\ ${ }^{\mathrm{c}}$ Redston Trevor Consulting, Ltd., Leeds, LS17 8RF, UK
}

Experimental set up for spectroelectrochemical measurements was designed. Uranium(III) ions, $\mathrm{UCl}_{6}{ }^{3-}$, are formed during anodic dissolution of metallic uranium and prolonged contact of U(IV)containing melts with uranium metal. $\mathrm{UCl}_{4}$ dissolution in $3 \mathrm{LiCl}-$ $2 \mathrm{KCl}$ melt leads to the formation of $\mathrm{UCl}_{6}{ }^{2-}$ ions. They undergo a two-step electrochemical reduction: $\mathrm{U}^{4+} \rightarrow \mathrm{U}^{3+}$ recharge followed by $\mathrm{U}$ deposition. Neptunium(IV) chloride dissolves in $3 \mathrm{LiCl}-2 \mathrm{KCl}$ melt producing $\mathrm{NpCl}_{6}{ }^{2-}$ ions. Electrochemical reduction of $\mathrm{Np}(\mathrm{IV})$ on a glassy carbon electrode results in the formation of $\mathrm{NpCl}_{6}{ }^{3-}$ ions and then leads to the deposition of neptunium metal. Electronic absorption spectra of uranium (III, IV, V and VI) and neptunium (III and IV) species in $3 \mathrm{LiCl}-2 \mathrm{KCl}$ eutectic were measured at $450{ }^{\circ} \mathrm{C}$.

\section{Introduction}

Molten salts have many applications in actinide processing and separations. Pyrochemical processes for the electrochemical separation of actinides and fission products from irradiated nuclear fuels have been studied for several years. These technologies have been developed to a pilot plant scale at Argonne National Laboratory, Argonne West, U.S.A and at Russian Institute of Atomic Reactors, Dimitrovgrad, Russia. At present the research is focused on the next generation of pyrochemical processes for actinide separations.

The development of safe and reliable separation technologies for actinides in molten salts relies on a sound understanding of the key electrochemical processes. An increased awareness of in situ actinide speciation could help underpin such electrochemical development. The most useful and direct information concerning coordination properties of actinides in molten salts can be obtained using spectroscopic techniques, including electronic absorption spectroscopy.

Combination of electrochemistry and spectroscopy in one spectroelectrochemical cell provides unambiguous information concerning speciation of a studied element. There are three reports dealing with high temperature spectroelectrochemistry. Smirnov and Potapov (1) investigated speciation of chromium and nickel in molten equimolar mixture of sodium and potassium chlorides, and Nagai et al. $(2,3)$ studied $\mathrm{UO}_{2}{ }^{2+} / \mathrm{UO}_{2}{ }^{+}$and $\mathrm{U}^{4+} / \mathrm{U}^{3+}$ equilibrium in $\mathrm{NaCl}-2 \mathrm{CsCl}$ melt. 
In the present work we describe the design of a spectroelectrochemical cell and a setup for conducting experiments in fused salts. Behaviour of uranium in lithium-potassium chloride eutectic mixture was studied at $450{ }^{\circ} \mathrm{C}$ and the obtained information concerning coordination and electrochemical properties of uranium(III) and (IV) species is presented. We conducted in situ spectroscopic studies of anodic dissolution of uranium, electrochemical oxidation of U(III) and electrochemical reduction of U(IV) and U(VI). The reaction between metallic uranium and uranium(IV)-containing melt was also studied. Additionally behaviour of neptunium species in $3 \mathrm{LiCl}-2 \mathrm{KCl}$ eutectic mixture at $450{ }^{\circ} \mathrm{C}$ was investigated by spectroelectrochemistry.

\section{Experimental}

The experiments were carried out at $450{ }^{\circ} \mathrm{C}$ in a standard $1 \mathrm{~cm}$ silica optical cell attached to a silica tube (20 mm i.d.) with two side-arms (Fig. 1). Glassy-carbon rod or platinum wire was used as a working electrode. The other glassy carbon or chlorine electrode in a quartz sheath served both as a counter and a quasi reference electrode and was separated from the bulk of the melt by a diaphragm. When studying anodic dissolution of metallic uranium, electrochemical oxidation of U(III) and electrochemical reduction of $\mathrm{U}(\mathrm{IV})$ or (VI), chlorine reference electrode also served as a counter electrode.

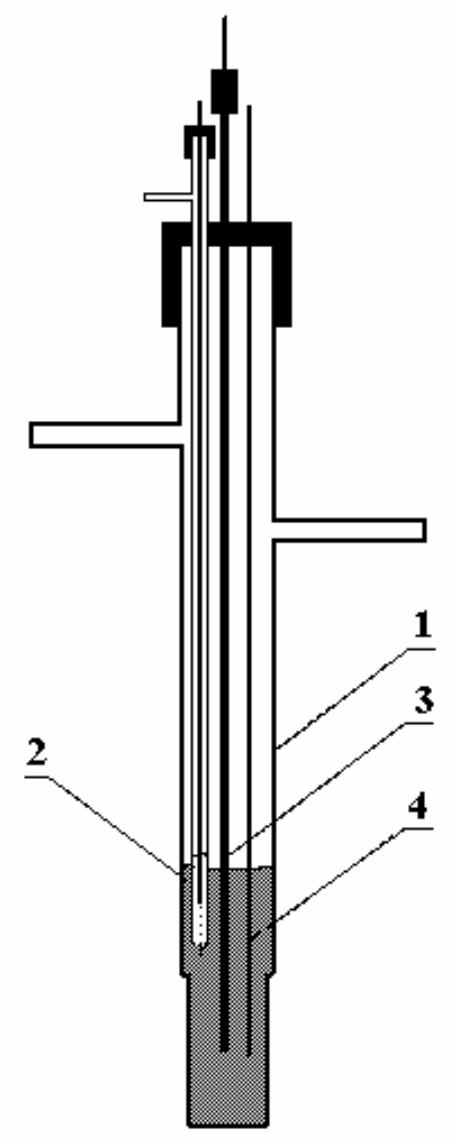

Figure 1. Experimental spectroelectrochemical cell (1 - silica optical cell, 2 - chlorine reference electrode, 3 - quartz capillary tube for chlorination, 4 -glassy-carbon working electrode). 
All experiments were performed in $3 \mathrm{LiCl}-2 \mathrm{KCl}$ eutectic (m.p. $360{ }^{\circ} \mathrm{C}$ ). To prepare $3 \mathrm{LiCl}-2 \mathrm{KCl}$ individual $\mathrm{LiCl}$ and $\mathrm{KCl}$ salts were dried for six hours at $250{ }^{\circ} \mathrm{C}$ then melted and sparged with a mixture of chlorine and hydrogen chloride for four hours, kept under vacuum for further three hours, and finally quenched under purified argon. Solid 3LiCl$2 \mathrm{KCl}$ was kept and manipulated in an argon filled dry box (Saffron). Uranium was introduced into the melt by anodic dissolution of the metal or by dissolving anhydrous uranium tetrachloride or uranyl chloride. Anhydrous uranyl chloride was prepared by reacting trioxide with gaseous $\mathrm{HCl}$ (Aldrich) at room temperature for five days, and uranium tetrachloride by refluxing $\mathrm{UO}_{3}$ with hexachloropropene for several days (4). Oxidation state of uranium was additionally determined by oxidimetry (5).

Neptunium(IV) containing samples were prepared by chlorinating hydrated neptunium(IV) oxide/chloride by hydrogen chloride in the melt. The neptunium stock solution in $1 \mathrm{M} \mathrm{HNO}_{3}$ had a neptunium concentration of $0.1 \mathrm{~mol} / \mathrm{l}$. UV-vis-nir spectroscopy indicated that neptunium in this solution was predominantly in the oxidation state +5 . An aliquot of this nitrate solution (containing $20 \mathrm{mg}$ of ${ }^{237} \mathrm{~Np}$ ) was divided evenly between four small screw top sample vials and the stoichiometric amount of $6 \mathrm{M}$ $\mathrm{NaOH}$ solution added to each vial to precipitate $\mathrm{NpO}_{2} \mathrm{OH} \cdot \mathrm{xH}_{2} \mathrm{O}$. Each vial was then placed into a centrifuge tube and firmly packed with paper to minimize any movement of the vial inside the centrifuge tube. The samples were centrifuged, the supernatant liquid removed and the remaining solid washed with distilled water. The vials were again centrifuged and the supernatant liquid discharged. The remaining solid was dissolved in $1 \mathrm{M} \mathrm{HCl}$ to form $\mathrm{NpO}_{2} \mathrm{Cl}$. The aliquots from each vial were then combined in a beaker. Several drops of HI solution (57 wt.\%) were added to this solution in order to convert $\mathrm{Np}(\mathrm{V})$ to $\mathrm{Np}(\mathrm{IV})$. The reduction was confirmed by UV-vis-nir spectroscopy but it did not go to completion and a small amount of $\mathrm{Np}(\mathrm{V})$ remained. The solution was evaporated to near dryness under a heat lamp. Residual was diluted with water and split evenly between 4 small screw top vials. The stoichiometric amount of $6 \mathrm{M} \mathrm{NaOH}$ was added to each vial to completely precipitate $\mathrm{Np}(\mathrm{OH})_{4}$. Each vial was centrifuged as described above, the supernatant liquid removed and the remaining solids washed with distilled water ( $c a .1 \mathrm{ml}$ per vial). The solutions were centrifuged and the supernatant removed. The solids were dissolved in $1 \mathrm{M} \mathrm{HCl}$ to form $\mathrm{NpCl}_{4}$ (an olive green solution). A UV-vis-nir spectrum of this solution confirmed that the majority of $\mathrm{Np}$ was present in the oxidation state +4 . The aliquots were transferred into the high temperature spectroscopy cell. The cell was sealed and purged with argon. The solution was evaporated to dryness using a heat lamp producing orange solid $\mathrm{NpCl}_{4}$. The cell was placed under vacuum for several hours still heated using the heat lamp to remove trace moisture from neptunium chloride. Then solid $3 \mathrm{LiCl}-2 \mathrm{KCl}$ eutectic was added to the spectroscopic cell containing prepared neptunium chloride in an inert atmosphere glove box, closed with a stopper, transferred into an optical furnace and heated to $450{ }^{\circ} \mathrm{C}$ under argon. Hydrogen chloride was bubbled through the melt for 1 hour to convert any remaining oxide-containing neptunium species into chlorides.

The progress of electrode reactions was followed by in situ electronic spectroscopy and voltammetry measurements. Spectroscopic measurements were performed using a fibre optic spectrophotometer Avantes Avaspec-2048-2 with an Avalight DH-S deuterium-halogen light source. PAR/EG\&G Model 263A potentiostat/galvanostat was used to control current passing through the cell or red-ox potential of the system. 


\section{Results and discussion}

\section{$\underline{\text { Reaction of U(IV) species by U metal }}$}

Absorption spectra of the melts after dissolution of uranium tetrachloride were typical of uranium(IV) species, $\mathrm{UCl}_{6}{ }^{2-}(5-7)$, with major bands at 505, 565 and $670 \mathrm{~nm}$, Fig. 2. The melt was light green and the average oxidation state of uranium was $c a 4.0$. The spectra didn't change during $\mathrm{HCl}$ bubbling through the melt.

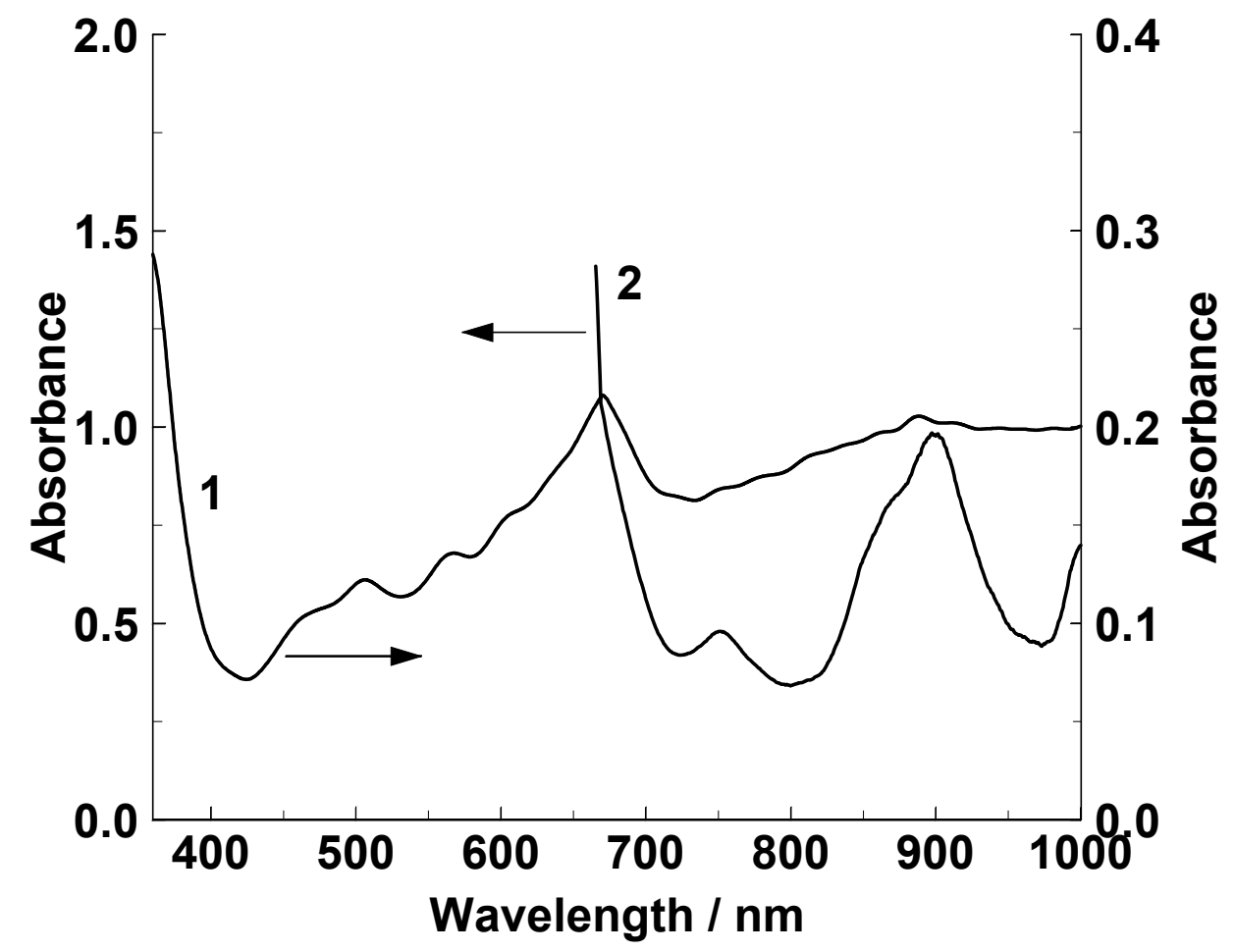

Figure 2. Electronic absorption spectra of uranium species in $3 \mathrm{LiCl}-2 \mathrm{KCl}$ melt at $450{ }^{\circ} \mathrm{C}$ (1-uranium(VI), 0.01 wt.\% U; 2 - uranium(III), 0.012 wt. \% U).

When uranium metal was introduced into the melt or a required potential was applied to a platinum working electrode, the color of the melt changed to deep purple. Absorbance increased considerably in the entire wavelength range (the extinction coefficient of U(III) is about two orders of magnitude higher than that of U(IV)). When uranium was used as a reductant, the potential between the platinum working electrode and the reference electrode didn't change. Despite the melt was purple, the fraction of uranium(III) ions was relatively small and the potential was close to the initial. A considerable length of time was necessary to convert all uranium into trivalent state, Fig. 3. After contacting $3 \mathrm{LiCl}-2 \mathrm{KCl}+\mathrm{UCl}_{4}$ melt with $\mathrm{U}$ metal for four hours the oxidation state of uranium (determined oxidimetrically in a quenched melt sample) was close to 3.0. When studying reduction of uranium tetrachloride by uranium metal it was not possible to obtain a good spectral picture of U(III) species in the entire wavelength range even when the initial concentration of $\mathrm{UCl}_{4}$ was very low. 


\section{$\underline{\text { Anodic dissolution of } U \text { metal }}$}

The best spectroscopy data for U(III) were obtained using anodic dissolution of uranium metal, Fig. 4. The spectra of uranium(III) contain peaks at around 465, 550, 750 and $900 \mathrm{~nm}$. The obtained spectral curves agree well with the literature data for uranium(III) ions $(6,8)$. Uranium(III) has $f^{3}$-electronic configuration and the ground level is ${ }^{4} \mathrm{I}_{9 / 2}$. The bands at 465 and $550 \mathrm{~nm}$ have higher intensity (by about an order of magnitude) compare to the others. According to the oxidimetry uranium anodically dissolves forming U(III) ions. Coulometry didn't give reasonable results, possibly due to high corrosion rate of uranium in $3 \mathrm{LiCl}-2 \mathrm{KCl}$ eutectic or/and interaction of $\mathrm{U}(\mathrm{III})$ ions with quartz. Summarizing current results and previously reported results of the X-ray absorption spectroscopy study of uranium speciation (7) we conclude that uranium anodic dissolution in $3 \mathrm{LiCl}-2 \mathrm{KCl}$ melt leads to the formation of $\mathrm{UCl}_{6}{ }^{3-}$ ions.

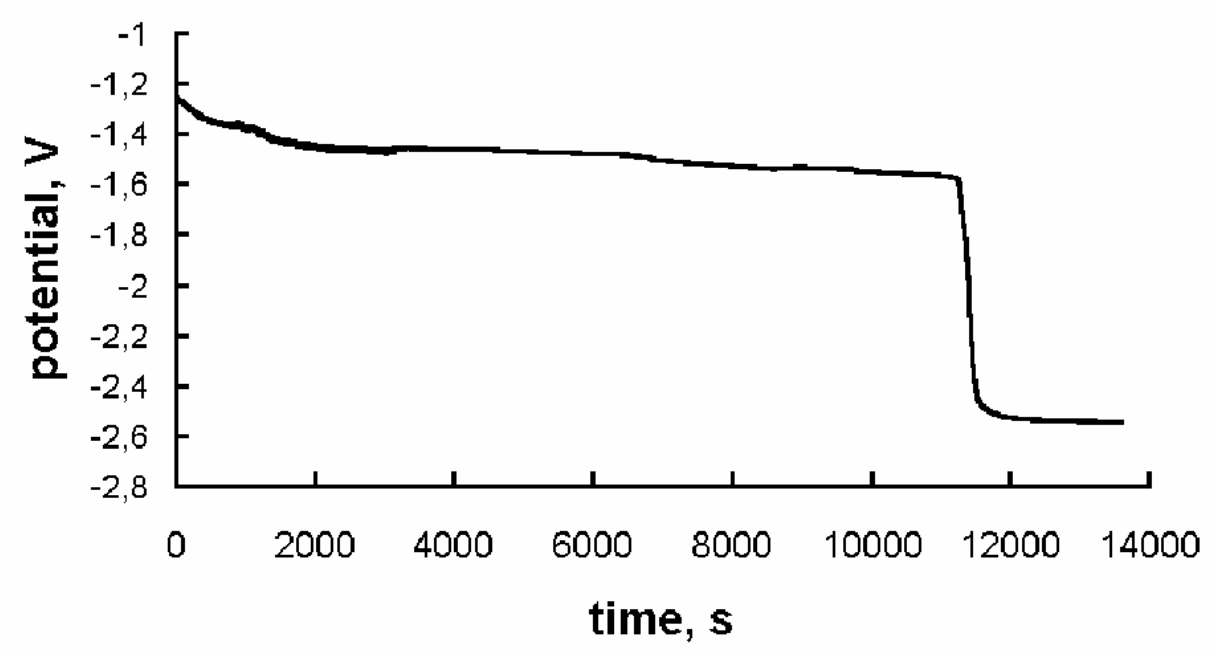

Figure 3. Potential change during contact of uranium metal with uranium(IV) containing melt (uranium content, wt. \%: initial - 0.01, final - 0.012).

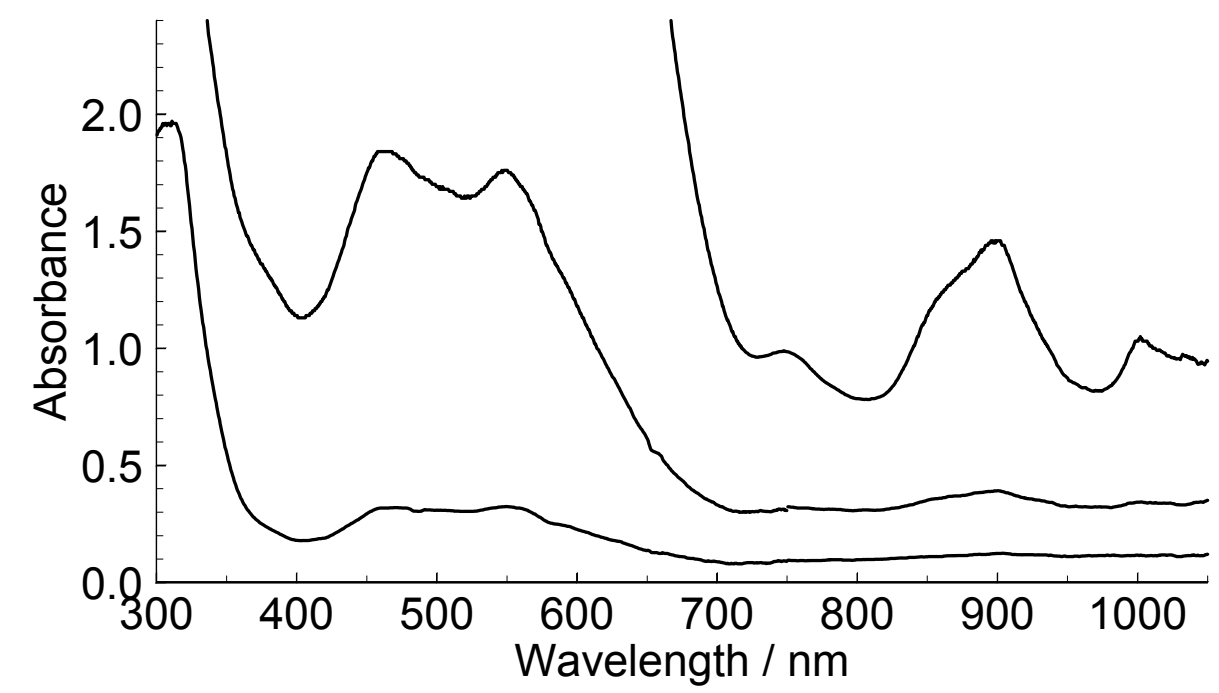

Figure 4. Electronic absorption spectra recorded during progressive anodic dissolution of $\mathrm{U}$ metal in $3 \mathrm{LiCl}-2 \mathrm{KCl}$ melt after $15 \mathrm{sec}, 1 \mathrm{~min}$, and $12 \mathrm{~min}$, respectively, $450{ }^{\circ} \mathrm{C}$, final $\mathrm{U}$ concentration 0.15 wt. $\%$. 


\section{Electrochemical reduction of uranium(IV)containing melts}

The electrochemical reduction of uranium(IV) species in chloride melts occurs in two stages, Fig. 5. First (around $-1.0 \mathrm{~V} v s . \mathrm{Cl}_{2} / \mathrm{Cl}^{-}$) is a reversible recharge of uranium(IV) to U(III). Further electroreduction leads to the formation of uranium metal.

We did not observe any isosbestic points when measuring spectra in the course of the electroreduction process, Fig. 6 . The reason for the absence of isobestic points is the large difference between extinction coefficients of uranium(IV) and (III) complexes. It is also necessary to take into account possible reaction of uranium(III)-containing melt with quartz. Nagai et al (3) have recently published a study describing isosbestic points in the UV-region during the reduction of U(IV) to U(III) but we were unable to reproduce them here.

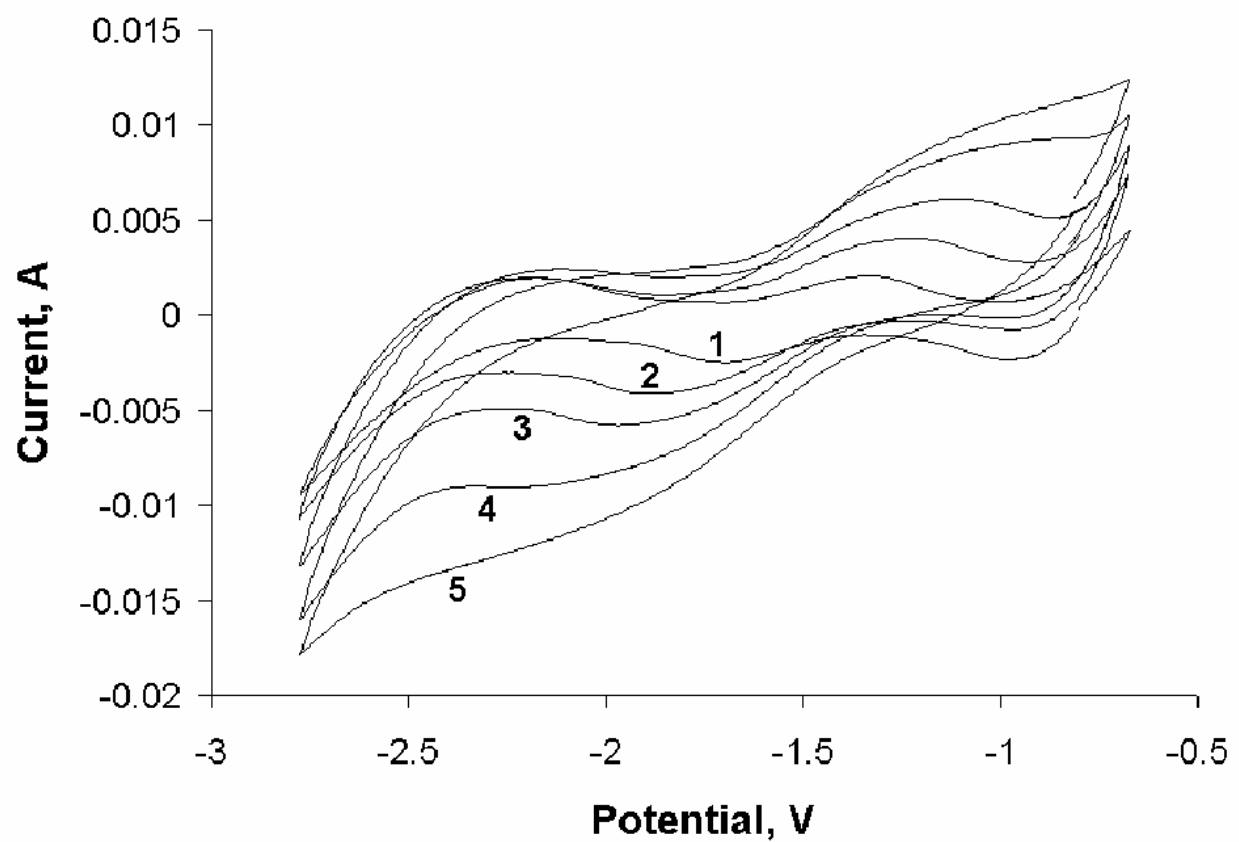

Figure 5. Cyclic voltamogramms of $\mathrm{LiCl}-\mathrm{KCl}_{\mathrm{UCl}} \mathrm{U}_{4}$ melt $(1.42 \mathrm{wt} \% \mathrm{U})$. Working electrode - glassy carbon ( $2.5 \mathrm{~mm}$ dia), reference electrode - chlorine. Scan rate, $\mathrm{mV} / \mathrm{sec}$ : $1-20,2-100,3-200,4-500,5-1000$.

Electrochemical reduction of uranium(VI) containing melts

Several experiments involving spectroelectrochemistry of uranium(VI) species were successfully performed in the $3 \mathrm{LiCl}-2 \mathrm{KCl}$ eutectic melt. These included cathodic reduction of uranyl-containing melts. The reduction of $\mathrm{UO}_{2}{ }^{2+}$ is a complex process together with the formation of uranium(V) ions, $\mathrm{UO}_{2}{ }^{+}$, some precipitation of solid $\mathrm{UO}_{2}$ was observed. The spectrum of uranium(VI) contains only a low energy edge of the charge transfer band, while the spectrum of uranium(V) chloro-complex ions $\left(\mathrm{UO}_{2} \mathrm{Cl}_{4}{ }^{3-}\right)$ contains two additional bands at 640 and $800 \mathrm{~nm}$, Fig. 7. 


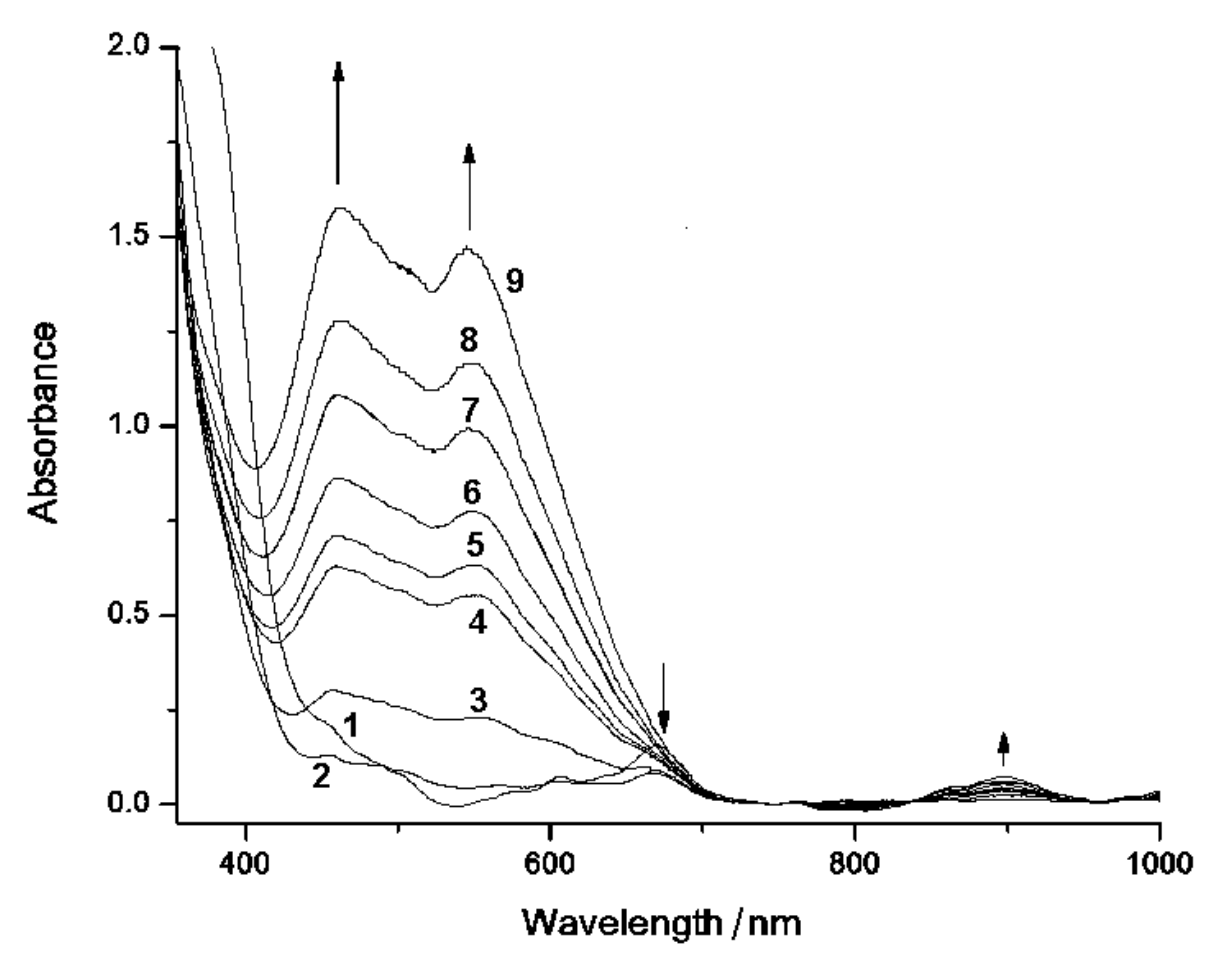

Figure 6. Spectra recorded during electrochemicall reduction of $3 \mathrm{LiCl}-2 \mathrm{KCl}+\mathrm{UCl}_{4}$ melt at $15 \mathrm{~mA}$ applied current. Uranium concentration $-0.1 \mathrm{wt}$. \%. Time of reduction, sec: $1-$ $0,2-20,3-40,4-60,5-80,6-120,7-140,8-160$, $9-180$.

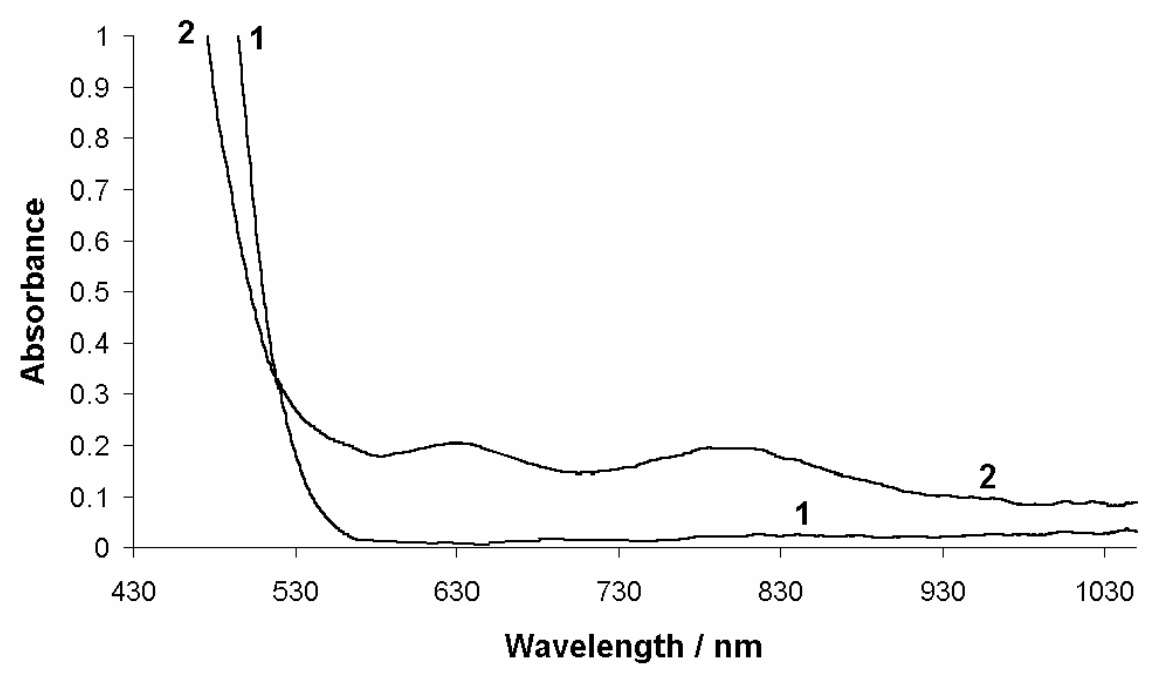

Figure 7. Electrochemical reduction of $3 \mathrm{LiCl}-2 \mathrm{KCl}+\mathrm{UO}_{2} \mathrm{Cl}_{2}$ melt at $10 \mathrm{~mA}$ applied current. Uranium content - 0.1 wt. \% (1 - initial spectra, 2 - after 240 sec of reduction).

\section{Neptunium spectroelectrochemistry}

The recorded spectrum of $\mathrm{Np}(\mathrm{IV})$ containing chloride melt is shown in Fig. 8. The spectral profile agrees very well with the data reported by Gruen et al. (9) and Barbanel' et al. (10). The major bands in Np(IV) spectrum are at 530, 585, 665, 740, 770, 837 and $936 \mathrm{~nm}$. Neptunium(IV) has $f^{3}$-electronic configuration (ground level is ${ }^{4} \mathrm{I}_{9 / 2}$ ). Using the literature data concerning neptunium coordination in molten chlorides (11) and the results 
of our previous EXAFS spectroscopy measurements of U(III), also having $f^{3}$-cofiguration, in $3 \mathrm{LiCl}-2 \mathrm{KCl}$ melt at $450{ }^{\circ} \mathrm{C}(7)$ we can conclude that neptunium(IV) in $3 \mathrm{LiCl}-2 \mathrm{KCl}$ eutectic forms octahedrally coordinated complex $\mathrm{NpCl}_{6}{ }^{2-}$ ions.

The progress of neptunium(IV) electrochemical reduction was followed by in situ electronic absorption spectroscopy. As shown in Fig. 8 the intensities of the bands corresponding to $\mathrm{Np}(\mathrm{IV})$ decrease. At the same time new peaks at $565,790,660,800$, 855 and $890 \mathrm{~nm}$ appear and grow. The spectral profile of the final recorded spectrum is typical of neptunium(III) chloro-complex (9-11). There are 5 isobestic points at 625,785 , 822,842 and $870 \mathrm{~nm}$ (Fig. 8) indicating that the total concentration of neptunium in the melt remained constant during the neptunium(IV) electoreduction, $\mathrm{NpCl}_{6}{ }^{2-} \rightarrow \mathrm{NpCl}_{6}{ }^{3-}$.

After complete conversion of $\mathrm{Np}(\mathrm{IV})$ to $\mathrm{Np}$ (III) the electrolysis was continued and the intensity of $\mathrm{Np}$ (III) spectrum began to decrease in the entire wavelength range due to reduction of $\mathrm{Np}$ (III) ions to neptunium metal.

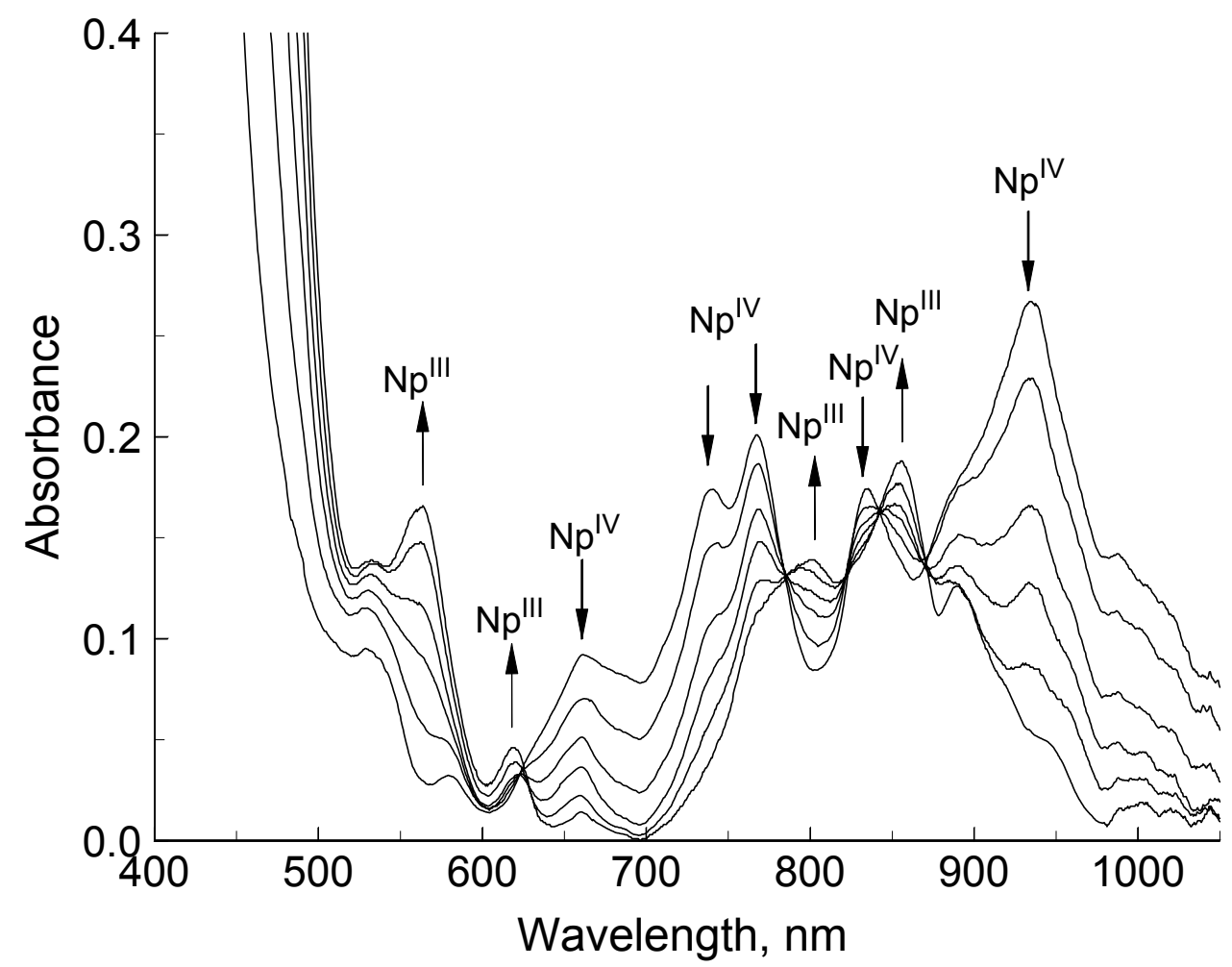

Figure 8. Spectra recorded during electrochemical reduction of $\mathrm{Np}$ (IV) to $\mathrm{Np}$ (III) in $3 \mathrm{LiCl}-2 \mathrm{KCl}$ eutectic melt at $450{ }^{\circ} \mathrm{C}$. Initial concentration of neptunium(IV) - ca. 0.015 $\mathrm{mol} / \mathrm{l}$. Total time of reduction - $1280 \mathrm{sec}$, current - $5 \mathrm{~mA}$.

\section{Acknowledgments}

IBP thanks INTAS (Grant No. 03-55-1453) for financial support. 


\section{References}

1. M. V. Smirnov and A. M. Potapov, Electrochim. Acta, 39, 143 (1994).

2. T. Nagai, T. Fujii, O. Shirai and H. Yamana, J. Nucl. Sci. Technol., 41, 690 (2004).

3. T. Nagai, A. Uehara, T. Fujii, O. Shirai, N. Sato and H. Yamana, J. Nucl. Sci. Technol., 42, 1025 (2005).

4. J. A. Hermann, J. F. Suttle and H. R. Hoekstra, in Inorg. Synthesis, Vol. 5, p. 143, McGraw-Hill Book Co. Inc., New York (1957).

5. V. A. Volkovich, I. May, A. I. Bhatt, T. R. Griffiths, J. M. Charnock and B. Lewin, in Proc. Int. Symp. Ionic Liquids, p. 253, Carry le Rouet, France (2003).

6. D. M. Gruen, in Fused salts, p. 331, McGraw-Hill Book Co. Inc., New York (1964).

7. V. A.Volkovich, I. May, C. A. Sharrad, H. Kinoshita, I. B. Polovov, A. I. Bhatt, J. M. Charnock, T. R. Griffiths and R. G. Lewin, in Recent Advances in Actinide Science, R. Alvarez, N. D. Bryan and I. May, Editors, p. 485, RSC Publishing, London (2006).

8. V. A. Volkovich, A. I. Bhatt, I. May, T. R. Griffiths and R. C. Thied, J. Nucl. Sci. Technol., Suppl. 3, 595 (2002).

9. D. M.Gruen, S. Fried, P.Graf and R. L. McBeth, in Proc. $2^{\text {nd }}$ Int. Conf. Peaceful Uses of Atom. Energy, Vol. 28, p.112, U.N., Geneva (1958).

10. Yu. A. Barbanel', V. N. Kotlin, V. V. Kolin and G. P. Chudnovskaya, Sov. Radiochimiya, 17, 929 (1975).

11. Yu. A. Barbanel', Coordination Chemistry of f-elements in Melts, Energoatomizdat, Moscow (1985) (in Russian). 